\title{
Key Factors Influencing qHBsAg Dynamics in Chronic Hepatitis B Patients During Treatment with Direct Acting Antivirals
}

\author{
Mihai Daniel DODOT ${ }^{1,2}$, Irina DUPORT-DODOT ${ }^{1,2}$, Letitia TOMA ${ }^{1,2}$, Laura ILIESCU ${ }^{1,2}$
}

\begin{abstract}
Chronic hepatitis B still represents a major challenge for clinicians and the public health service even years after the development of an efficient vaccine and potent antiviral agents. The major actual problems in treating chronic hepatitis B (HBV) patients are represented by the lack of reliable biomarkers which can predict the response to specific types of therapy. With the availability of different treatment options for chronic HBV patients at our disposal [Pegylated Interferon (pegIFN), Nucleosidic Analogues (NUCs), combined therapies] the results of treatment remain modest. A better selection of patients for each treatment regimen requires an early predictive factor for treatment efficiency especially with NUC therapies witch tend to have a very long treatment period (up to five decades) for reaching HBs clearance. The main objective of our study is to identify the most important predictive factors for early NUC treatment response. We observed that baseline quantitative HBs antigen (qHBsAg) levels, rapid qHBsAg decrease rate in the first year of treatment and high ALT levels are important predictors for HBs antigen loss while the decrease rate of HBV-DNA and the treatment regimen are not reliable predictive factors.
\end{abstract}

Keywords: Chronic hepatitis B, HBs antigen, Seroconversion, Nucleosidic analogues (NUCs), treatment response.

\section{Rezumat}

În pofida existenței unui vaccin eficient, dar și a unor terapii antivirale eficiente, hepatita cronică VHB reprezintă o provocare majoră, atât pentru sistemul de sănătate, cât și pentru clinicieni. Impedimentele majore actuale în ceea ce privește tratamentul pacienților infectați cronic cu VHB sunt reprezentate de lipsa unor biomarkeri care să poată anticipa cu precizie răspunsul la terapiile antivirale. În ciuda existenței multiplelor opțiuni terapeutice [Interferon peghilat (Peg-INF), Analogi Nucleozidici (AN), terapii combinate], rata de vindecare rămâne scăzută. Selectarea unui tratament specific fiecărui pacient impune necesitatea unui factor predictiv precoce a evoluției bolii sub tratament, în special în cazul utilizării antiviralelor directe, ce necesită perioade de administrare de ordinul decadelor pentru a se obține seroconversia în sistem HBs. Obiectivul principal al prezentului studiu este acela de a identifica cei mai importanți factori predictivi pentru răspunsul precoce la tratamentul VHB cu AN. Am constatat că un nivelul bazal scăzut al AgHBs cantitativ la momentul inițierii terapiei, scăderea rapidă a nivelului AgHBs în primul an de tratament și valorile crescute ale ALT prezic frecvent negativarea AgHBs pe când rata de scădere a nivelului ADN-VHB și tipul de tratament folosit (Entecavir sau Tenofovir) nu se corelează cu eliminarea AgHBs.

Cuvinte cheie: Hepatită cronică B, antigen HBs, Seroconversie, Analogi Nucleozidici (AN), răspuns therapeutic.

${ }^{1}$ Department of Internal Medicine, Fundeni Clinical Institute, Bucharest, Romania

2 "Carol Davila" University of Medicine and Pharmacy, Bucharest,

Romania

\section{Corresponding author.}

Mihai Daniel DODOT, Fundeni Clinical Institute, 258 Fundeni Avenue, Bucharest, Romania.

E-mail: Dodot.daniel87@gmail.com 


\section{BACKGROUND AND AIMS}

In this study on 208 patients with chronic hepatitis B infection treated with Entecvir or Tenofovir we want to determine the main factors that can predict an early response to nucleosidic analogues (NUC) treatment in order to better determine wich patients have a better chance to attain quantitative $\mathrm{HBs}$ antigen ( $\mathrm{qHBsAg}$ ) clearance or HBs seroconversion under Entecavir or Tenofovir treatment and what patients may need treatment discontinuation or switch to a different type of treatment.

\section{INTRODUCTION}

Even with the existence of an efficient vaccine against hepatitis $\mathrm{B}(\mathrm{HBV})$ which has been developed more than 30 years ago, chronic HBV infection remains a major global health issue with approximately 257 million (3.5\% of the population) chronically infected worldwide. Long term complications that account for $96 \%$ of the deaths due to viral hepatitis are cirrhosis and hepatocellular carcinoma (HCC) which is the third leading cause of mortality worldwide ${ }^{1}$.

Even though acute infection in adults is cleared in over $90 \%$ of cases, the remaining approximately $10 \%$ will develop chronic hepatitis with a spontaneous annual viral clearance as low as $0.1 \%$ in endemic areas, making it a lifelong infection with subsequent risk of developing complications as mentioned above ${ }^{2,3}$.

The aim of currently available treatment guidelines for patients with chronic hepatitis B is to improve survival by delaying disease progression to cirrhosis and HCC4. This is achieved through long term suppression of HBV-DNA. Additional goals of antiviral therapy are to prevent mother to child transmission, hepatitis $B$ reactivation and the prevention and treatment of $\mathrm{HBV}$-associated extrahepatic manifestations ${ }^{4}$.

Seroconversion in $\mathrm{HBe}$ system with or without the appearance of $\mathrm{HBe}$ antibodies represents another endpoint of the treatment as it reflects a partial immune control of the infection. An additional endpoint is the normalization of liver function, reflected by normal ALT levels which is normally obtained after prolonged antiviral treatment. The ultimate goal of the treatment is the loss of $\mathrm{HBsAg}$ with or without anti-HBs seroconversion as it indicates a profound viral suppression- termed the functional cure ${ }^{4,5}$. However, this is rarely achieved. Currently available treatment options involve either a determinate course of pegylated IFNalfa which stimulates the immune system against HBV or the use of an oral antiviral which suppresses viral replication (HBV DNA below standard techniques of detection) for an indefinite duration. Although Peginterferon has a higher $\mathrm{HBsAg}$ clearance rate than direct acting antiviral (DAA) therapy ( $4 \%$ and $<1 \%$ respectively) in $\mathrm{HBeAg}$ negative patients ${ }^{6-8}$, $\mathrm{HBs} \mathrm{Ag}$ loss is uncommon with both options ${ }^{9,10}$.

Over the past decade a lot of interest and research has been put into the clinical usefulness of quantitative $\mathrm{HBs} A g$. Nowadays commercial assays have become widely available in measuring $\mathrm{qHBsAg}$ and at a price far lower and accessible than genetic testing ${ }^{11}$. The quantification of $\mathrm{HBsAg}$ level has been standardized in $\mathrm{IU} / \mathrm{mL}$ and nowadays it is almost indispensable for the evaluation of patients, the decision for treatment option, but also plays a role in predicting treatment response as $\mathrm{HBsAg}$ seroclearance is considered the ultimate goal of therapy ${ }^{12}$.

$\mathrm{HBsAg}$ is the most abundant viral protein produced during hepatitis $\mathrm{B}$ virus (HBV) replication, and its presence in the serum for $>6$ months is a hallmark of chronic $\mathrm{HBV}$ infection ${ }^{4}$. HBsAg represents the surface antigen of the HBV. It is produced either through translation of mRNA from transcriptionally active cccDNA, or through the translation of viral genes transcribed from integrated DNA sequences in the host genome, also known as truncated HBsAg. It is found as an envelope of the infectious virion and it can be also found as a non-infectious empty envelope which has no core component. Therefore the level of $\mathrm{HBsAg}$ is being considered a surrogate marker of transcriptionally active cccDNA ${ }^{11,13}$.

During the natural history of chronic hepatitis B, spontaneous $\mathrm{HBsAg}$ clearance is rarely achieved. Annual $\mathrm{HBs} \mathrm{Ag}$ seroclearance rate can range from a low of $0.12 \%$ to a high of $2.38 \% \%^{2,14,15}$. However there are a few factors predicting viral clearance. Studies conducted have shown that baseline qHBsAg level $<200 \mathrm{IU} / \mathrm{mL}$, correlates with a higher rate of $\mathrm{HBs} \mathrm{Ag}$ loss and could predict future seroclearance in 1-3 years ${ }^{16-20}$.

With respect to the treatment, during NUC therapy the decrease in the $\mathrm{qHBsAg}$ is much slower compared to interferon (IFN) based treatment. The reason is that NUCs do not target directly the cccDNA, even though they inhibit more efficiently HBV-DNA. On the other hand IFN based therapy has an immune stimulating effect and could explain the more dramatic decrease in $\mathrm{qHBsAg}^{12}$.

Studies conducted show that the efficiency with which NUC therapy inhibits HBV DNA is over $95 \%{ }^{21}$, however the decline in $\mathrm{qHBs} \mathrm{Ag}$ is very slow and very 
Key Factors Influencing qHBsAg Dynamics in Chronic Hepatitis B Patients During Treatment

small, with a $\log <0.1 \log 10 \mathrm{IU} / \mathrm{mL} .^{22,23}$ in $\mathrm{HBeAg}$ negative patients. Moreover loss of $\mathrm{HBsAg}$ has been reported to be $0.33 \%$ per year during entecavir and in one study was reported only 1 out of 375 patients who achieved functional cure after 7 years of Tenofovir (TDF) treatment. Moreover decline in $\mathrm{qHBsAg}$ varies among different genotypes ${ }^{11}$.

Quantitative serum HBsAg levels correlate with the transcriptional activity of intrahepatic covalently closed circular DNA (cccDNA) of HBV in patients with hepatitis $\mathrm{B}$ e antigen ( $\mathrm{HBeAg}$ )-positive chronic hepatitis $\mathrm{B}(\mathrm{CHB})$, but not in those with $\mathrm{HBeAg-negative}$ $\mathrm{CHB}^{24}$.

Studies have shown that patients with persistent ALT elevations at the beginning and/or during NUC treatment showed a more significant decrease in qHBsAg. This might be explained by the immune mediated hepatocytolysis as reflected by the high ALT levels is associated with cccDNA loss and greater and faster qHBsAg loss. One study reported treatment ALT elevation during early phase of DAA therapy, reflecting immune restoration induced by strong HBV suppression that could indicate an acceleration in $\mathrm{qHBsAg}$ decline in $\mathrm{CHB}$ patients with pretherapy $\mathrm{ALT}<5 \mathrm{X}$ ULN and $\mathrm{AFP}<20 \mathrm{ng} / \mathrm{mL}^{25}$. However $\mathrm{HBsAg}$ seroconversion was not statistically significant.

Neither of the current therapies achieve a "complete" cure, primarily because of the persistence of the active transcriptionally active $\mathrm{HBV}$ covalently closed circular DNA (cccDNA) minichromosome in the nuclei of infected cells ${ }^{26}$.

Even though current therapy options results in durable suppression of viral replication in the majority of patients with chronic hepatitis $B$ virus (HBV) there is an urgent need for the developing of more potent treatment regimens that can achieve the functional cure. In order to accomplish the ultimate goal, further research is needed to understand the molecular behavior of hepatitis $B$ virus.

\section{PATIENTS AND METHODS}

\section{Study design}

This was a prospective analysis on $\mathrm{CHB}$ patients who underwent antiviral treatment with Entecavir or Tenofovir over a long period of time in the Internal Medicine clinic of "Fundeni" Clinical Institute. The patients included were $\mathrm{HBeAg}$ negative when enrolled or clea- red $\mathrm{HBe}$ antigen during the treatment period. All the patients included in the study achieved virological response (negative HVB DNA) within the first 6 months of NUC treatment. All the patients were $>18$ years of age, had normal or mildly impaired hepatic function, and had no significant comorbidities. The study duration was 3 years and was conducted in accordance with all the regulatory requirements and principles of the Declaration of Helsinki. Written informed consent was obtained before initiating the study procedures.

\section{Patients}

The study population consisted of 208 consecutive patients treated with Entecavir or Tenofovir who achieved virological response (negative HVB-DNA) during the first 6 months of Entecavir or Tenofovir treatment. The patients were followed for a period of at least 3 years after achieving virological response by means of measuring Quantitative HBs antigen (qHBsAg), transaminases, alfa-fetoprotein (AFP), Bilirubin, and other factors. The patients were treated during 3 years - January 2015 to January 2018. All patients had no contraindications for NUC therapy, aged from 18 to 80 years old, with a mean age of 44 years. HIV or hepatitis C coinfection, autoimmune hepatitis, cirrhosis, neoplastic disorders and active alcohol consumption were exclusion criteria.

$\mathrm{CHB}$ was documented by presence of $\mathrm{HBs}$ antigen and HVB DNA in the serum of patients for more than 6 months, liver biopsy or FIBROMAX were used to establish the degree of liver fibrosis at baseline and $\mathrm{Fi}^{-}$ broscan was used to assess the degree of fibrosis during the treatment period. The patients were evaluated at a 3 month interval - at each visit we determinded qHBs antigen, transaminases, bilirubin, albumin, INR, platelet count. Liver ultrasound and Fibroscan were performed every 6 months.

\section{Laboratory measurements}

Quantitative HBs antigen was determined by automated chemiluminiscent microparticle immunoassay, HVB DNA was determined by Real-time PCR (TaqMan), HBeAg and anti-HBe were detected using electrochemiluminescence immunoassay (ECLIA). Liver function tests including bilirubin levels, albumin and aspartate aminotransferase levels were determined using an automated biochemical analyzer. Peripheral blood platelets were counted using an automated blood cell analyzer. 


\section{Statistical analysis}

Statistical analysis was performed using SPSS version 21. Continuous variables expressed as mean \pm standard variation or median and categorical variables as absolute or relative frequencies. Characteristics were compared using Mann-Whitney or two-sample Students's $t$ tests for continuous variables, Chi-square and Fishers's exact tests for categorical variables. A two-sided $\mathrm{P}$ $<0.05$ was considered statistically significant.

\section{RESULTS}

\section{Baseline characterisitics of the study population}

We enrolled 208 patients: 128 (61.5\%) male and 80 (38.5\%) female, aging between 18 and 80 years old (mean age 44 years), 164 (78.8\%) were HBe antigen negative and 44 (21.2\%) HBeAg positive, mean baseline HBV DNA was above $20000 \mathrm{UI} / \mathrm{mL}$ in all patients, 119 (58.33\%) had stage 2 liver fibrosis (F2) and 85 (41.66\%) were F3. Median qHBsAg at baseline was $5184 \mathrm{UI} / \mathrm{ml}$. The levels of HBV DNA and qHBsAg were significantly higher in $\mathrm{HBeAg}$ positive patients $(\mathrm{p}<0.001)$, and tended to be lower in patients with F3 than in those with F2. 103 (50.4\%) of the patients received Entecavir and 101(49.5\%) received Tenofovir disoproxil fumarate (Table 1).

\section{Virological response}

All 208 patients reached undetectable levels of HVB DNA at treatment month 6 . Over the 3 years of treatment the median levels of $\mathrm{qHBsAg}$ decreased slowly with a faster rate of decrease during the first 12 months, probably on the behalf of the HBe positive patients who lost the $\mathrm{HBe}$ antigen in this period and due to the $\mathrm{HBe}$ seroconversion, the $\mathrm{qHBsAg}$ decrease was much faster in these patients. Over the second and the third year of treatment the rate of HBsAg loss decreased steadily. After month 12 and 21 we observed an increase in $\mathrm{qHBsAg}$ levels, followed by a faster decline in the next months (Figure 1). 3 patients achieved $\mathrm{HBs} \mathrm{Ag}$ clearance, all of them were $\mathrm{HBe}$ negative patients with very low levels of $\mathrm{qHBsAg}(<100 \mathrm{UI} / \mathrm{ml})$. Patients with high levels of $\mathrm{qHBsAg}$ at baseline had high rate of decrease (>1000 UI/ml/year) in the first year of treatment, but this rate decreased in the second and the third year of treatment.

\section{qHBsAg kinetics}

Among most patients HBs antigen levels decreased slowly but significantly $(0.5 \mathrm{log}$ in the first year to 0.1 to $0.05 \mathrm{log}$ in the later phases - Table 2). The qHbsAg decrease was significantly higher in $\mathrm{HBe}$ positive $\mathrm{pa}-$ tients, and less significant in $\mathrm{HBe}$ negative and $\mathrm{HBe}$ positive that became $\mathrm{HBe}$ negative patients during the treatment period (mostly in the first year of treatment). Patients with low baseline HBs antigen levels had higher decrease rates under treatment while $\mathrm{HBe}$ negative patients with high baseline levels of HBs antigen had lower decrease rate. In some of these patients $\mathrm{HBs}$ antigen levels were stationary or increasing under NUC treatment. The 3 patients that achieved HBs antigen clearance had very low $\mathrm{HBs}$ antigen level at baseline $(<200 \mathrm{UI} / \mathrm{ml})$ and had significant $\mathrm{HBs}$ antigen loss under treatment.

Table 1. Baseline characteristics of the study population

\begin{tabular}{|c|c|c|}
\hline Characterisitics & Patients $(n=208)$ & $P$ value \\
\hline Age (years), mean \pm SD & 44 & 0.002 \\
\hline Gender (male/female), $\mathrm{n}$ & $128 / 80$ & 0.1 \\
\hline Baseline HVB DNA (UI/ml) load mean \pm SD & $78230 \mathrm{UI} / \mathrm{ml}$ & $<0.001$ \\
\hline ALT levels $(\mathrm{UI} / \mathrm{ml})$ mean $\pm \mathrm{SD}$ & $43 \mathrm{UI} / \mathrm{ml}$ & 0.01 \\
\hline Baseline HBs antigen levels $(\mathrm{UI} / \mathrm{ml})$ mean $\pm \mathrm{SD}$ & $5184 \mathrm{UI} / \mathrm{Im}$ & $<0.001$ \\
\hline Liver fibrosis grade (F2/F3) & $119 / 85$ & 0.02 \\
\hline
\end{tabular}

Table 2. qHBs antigen dinamics during the treatment period

\begin{tabular}{|l|l|l|l|l|l|l|l|l|l|l|}
\hline & Baseline & Month 1 & Month 3 & Month 6 & Month 9 & Month 12 & Month 18 & Month 24 & Month 36 & Month 48 \\
\hline $\begin{array}{l}\text { Hbs antigen decrease } \\
\text { rate (log) }\end{array}$ & 1 & 0.119 & 0.178 & 0.7 & 0.618 & 0.01 & 0.124 & 0.325 & 0.062 & 0.048 \\
\hline p value & & 0.043 & 0.025 & 0.001 & 0.001 & 0.099 & 0.0733 & 0.0594 & 0.0645 & 0.53 \\
\hline
\end{tabular}


Figure 1. qHBs antigen levels at each

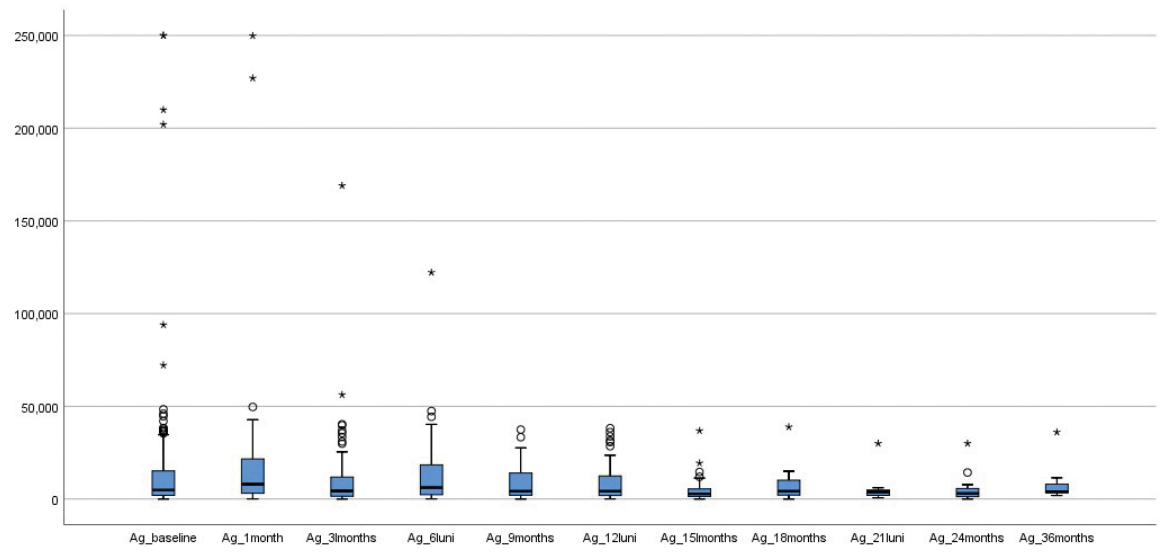
study visit.

Figure 2. HBs antigen kinetics under each of the two treatment regimens.

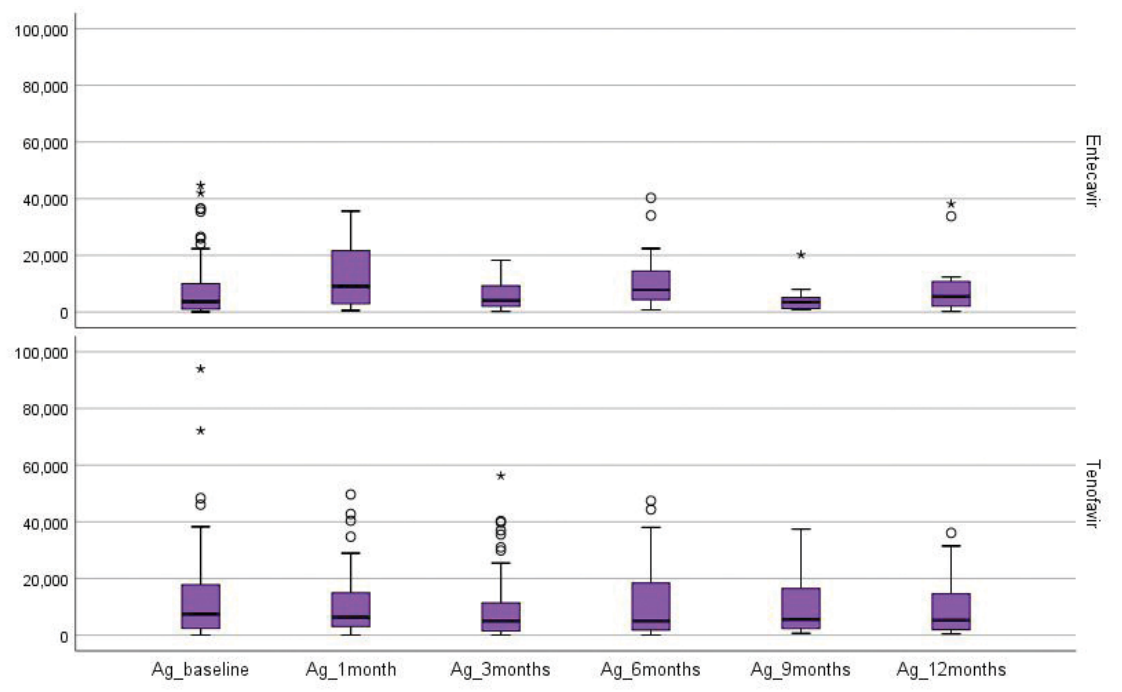

\section{DISCUSSION}

HBs antigen remains a very important serological marker in HBV chronic infection. It has been proven that $\mathrm{HBs}$ antigen levels correlate with the amount of intrahepatic covalently closed circular DNA (cccDNA), and its transcriptional activity ${ }^{27}$. The ultimate goal in $\mathrm{HBV}$ therapy is $\mathrm{HBs}$ antigen loss and seroconversion to anti-HBs, facts that translate to efficient treatment response and disease resolution. Even in patients who achieve SVR and HBe seroconversion it is known that continuous long-term NUC treatment does not ensure HBs antigen clearance and relapses are common upon treatment discontinuation. It is extremely important to identify on-treatment parameters for predicting patient response and nonresponse to long term NUC treatment, especially to identify the patients that are likely to achieve HBs antigen loss. Important predictors of $\mathrm{HBs}$ antigen loss are low baseline HBs antigen levels, high ALT levels, female gender, younger age, and some genotypes of $\mathrm{HBV}^{28}$. It was shown that low baseline levels of $\mathrm{HBs}$ antigen are more reliable as a predictor factor for good response to treatment than serum HBV DNA levels in $\mathrm{HBeAg}$ positive patients ${ }^{29,30}$. The most important characteristic of the patients in our study that achieved $\mathrm{HBs}$ antigen loss was the low baseline HBsAg level (<200 UI/ml). The baseline HBV DNA or the treatment regimen (TDF or ENT), didn't have a significant impact on the rate of $\mathrm{HBs}$ antigen loss. All patients achieved undetectable levels of HBV DNA during the first year of treatment but the HBs antigen loss did not correlate with HBV DNA loss, neither did it differ between patients treated with ENT or TDF 
(Figure 2). The results suggested that $\mathrm{HBe}$ positive patients have a higher rate of $\mathrm{HBs}$ antigen loss than $\mathrm{HBe}$ negative patients. After achieving HBe seroconversion the rate of $\mathrm{HBs}$ antigen loss tends to decrease and equal that of $\mathrm{HBe}$ negative patients, low baseline $\mathrm{HBs}$ antigen levels in both $\mathrm{HBe}$ positive and negative patients predict a high probability of $\mathrm{HBs}$ antigen loss.

In the future individualized treatment programs should be considered according to baseline HBs antigen levels. Studies show that extending the duration of therapy can increase the rate of SVR in $\mathrm{HBeAg}$ negative patients treated with NUC or PEG-IFN ${ }^{31}$. In the current study we observed an increased decrease rate in the first year of treatment followed by a slower rate in the following years especially for patients with high values of $\mathrm{HBs}$ antigen. Following up patients for longer periods may offer additional information about $\mathrm{HBs}$ antigen kinetics in patients with high antigen levels and slow decrease rates.

Optimized treatment and careful patient selection are essential in order to increase the rate of success and to minimize adverse effects. Studies with PEG-IFN treatment on patients previously treated with NUC show that patients that had very low or no HBs antigen loss during NUC therapies may have significant rates of $\mathrm{HBs}$ antigen loss during IFN treatment ${ }^{32,33}$. According to these results patients under NUC treatment with no $\mathrm{HBs}$ antigen loss and no contraindications may be suitable candidates for PEN-IFN therapy.

Patients with rapid decline in HBs antigen levels have a significantly higher chance to achieve HBs antigen loss or $\mathrm{HBs}$ seroconversion than those with low decline rate. In the present study HBsAg levels decreased significantly in the first year of treatment, however in the following years the rate of $\mathrm{HBs}$ antigen decrease became slower.

Although in most patients it will take decades to clear HBs antigen there are a few cases were HBs antigen loss was achieved in one or two years. Taking these predictors into account in the future the treatment regimen should be adapted for each patient. Patients with low baseline $\mathrm{HBs}$ antigen levels and patients with high rate of $\mathrm{HBs}$ antigen decrease ( $>1 \mathrm{log} /$ year) will continue current treatment (ENT or TDF), patients with high $\mathrm{HBs}$ antigen levels and low rates of $\mathrm{HBs}$ antigen decrease under NUC treatment may be worthy candidates for PEG-IFN therapy or new anti-HBV molecules.
The fact that all patients achieved undetectable HBV DNA reflects effective reduction in viral replication but the low decrease in $\mathrm{HBs}$ antigen levels shows a less effective reduction in the translation of $m R N A s$ produced by transcriptionally active cccDNA or integrated sequences ${ }^{34}$. In most patients the kinetics of HBV-DNA and HBs antigen levels are dissociated. Several studies have shown that combining cutoff levels for $\mathrm{HBsAg}$ and $\mathrm{HVB}$ DNA can identify patients with inactive disease ${ }^{35,36}$, while other studies showed that patients with parallel HBs antigen and HBV DNA kinetics tend to be sustained responders ${ }^{37-39}$.

In the present study all the patients had baseline HBV DNA values $>20000 \mathrm{UI} / \mathrm{ml}$ and achieved viral response in the first year of treatment, most of them within the first 6 months, however the decrease in HBs antigen levels was much slower than that of HVB DNA. Furthermore the rate of $\mathrm{HBs}$ antigen decrease became less important after HBV DNA clearance even if viral response was the essential objective of the treatment and the main indicator of efficient viral suppression.

\section{CONCLUSIONS}

In summary the results from this study show that the most important predictor for $\mathrm{HBs}$ antigen clearance in HBV patients treated with ENT or TDF is a low baseline $\mathrm{HBs}$ antigen level. Another important predicto is sustained and rapid decline of HBs antigen level during treatment. HBe positive patients tend to have a faster decline in $\mathrm{HBs}$ antigen levels but after $\mathrm{HBe}$ seroconversion the rate of decrease becomes less significant. In patients with high levels of HVB DNA the decline of $\mathrm{HB}$ s antigen is higher until HVB DNA becomes undetectable, then the decrease in HBs antigen levels becomes less significant. This explains the rapid decrease in HBs antigen levels in the first months of treatment $(0.5 \log )$ and the slower decline in the late period of treatment (0.1-0.05 log).

Compliance with ethics requirements: The authors declare no conflict of interest regarding this article. The authors declare that all the procedures and experiments of this study respect the ethical standards in the Helsinki Declaration of 1975, as revised in 2008(5), as well as the national law. Informed consent was obtained from all the patients included in the study. 


\section{References}

1. www.Who.int. Global hepatitis report 2017; 2017

2. Chu C.M., Liaw Y.F.HBsAg seroclearance in asymptomatic carriers of high endemic areas: appreciably high rates during a longterm follow-up Hepatology, 45 (2007), pp. 1187-1192

3. Liu C.J., Kao J.H., Chen D.S.Mixed hepatitis B virus genotype infections: the more, the worse? Hepatology, 44 (2006), p. 770

4. European Association for the Study of the Liver. EASL 2017 Clinical Practice Guidelines on the management of hepatitis B virus infection. Journal of Hepatology 2017 vol. 67 j 370-398

5. Chen, Y. C. \& Liaw, Y. F. Pharmacotherapeutic options for hepatitis B. Expert. Opin. Pharmacother. 17, 355-367 (2016)

6. Kim, G. A. et al. HBsAg seroclearance after nucleoside analogue therapy in patients with chronic hepatitis B:clinical outcomes and durability. Gut 63, 1325-1332 (2014)

7. Jeng, W. J., Chen, Y. C., Chien, R. N., Sheen, I. S. \& Liaw, Y. F. Incidence and predictors of hepatitis B surface antigen seroclearance after cessation of nucleos(t)ide analogue therapy in hepatitis B e antigen- negative chronic hepatitis B. Hepatology 68, 425-434 (2018)

8. Buti, M. et al. Seven- year efficacy and safety of treatment with tenofovir disoproxil fumarate for chronic hepatitis B virus infection. Dig. Dis. Sci. 60, 1457-1464 (2015)

9. Marcellin, P., Lau, G.K., Bonino, F. et al. Peginterferon alfa-2a alone, lamivudine alone, and the two in combination in patients with HBeAg-negative chronic hepatitis B. N Engl J Med. 2004; 351: 1206-1217

10. Lau, G.K.K., Piratvisuth, T., Luo, K.X. et al. Peginterferon alfa-2a, lamivudine, and the combination for $\mathrm{HBeAg}$-positive chronic hepatitis B. N Engl J Med. 2005; 352: 2682-2695

11. Liaw YF. Clinical utility of HBV surface antigen quantification in HBV e antigen negative chronic HBV infection. Nat Rev Gastroenterol Hepatol. 2019 Oct;16(10):631-641

12. Cornberg, M., Wong, V.W-S., Locarnini, S., Brunetto, M., Janssen, H.L.A., Chan, H.LY., The role of quantitative hepatitis b surface antigen revisited, Journal of Hepatology (2016)

13. Wursthorn $\mathrm{K}$ et al., Kinetics of Hepatitis B Surface Antigen Decline During 3 Years of Telbivudine Treatment in Hepatitis B e Antigen-Positive Patients. Hepatology. 2010 Nov;52(5):161120

14. Liu J, Yang $\mathrm{HI}$, Lee $\mathrm{MH}$, et al. Incidence and determinants of spontaneous hepatitis B surface antigen seroclearance: a community-based follow-up study. Gastroenterology 2010;139:474-482

15. Yee Hui Yeo. Factors Associated With Rates of HBsAg Seroclearance in Adults With Chronic HBV Infection: A Systematic Review and Meta-analysis. Gastroenterology. 2019 Feb;156(3):635646.e9

16. Chan, H. L., Wong, G. L., Tse, C. H., Chan, H. Y. \& Wong, V. W. Viral determinants of hepatitis $B$ surface antigen seroclearance in hepatitis B e antigen negative chronic hepatitis B patients. J. Infect. Dis.204, 408-414 (2011)

17. Tseng, T. C. et al. Serum hepatitis B surface antigen levels predict surface antigen loss in hepatitis $B$ e antigen seroconverters. Gastroenterology 141, 517-525 (2011).

18. Chen, Y. C., Jeng, W. J., Chu, C. M. \& Liaw, Y. F. Decreasing levels of $\mathrm{HBsAg}$ predict $\mathrm{HBsAg}$ seroclearance in patients with inactive chronic hepatitis B virus infection. Clin. Gastroenterol. Hepatol. 10, 297-302 (2012)

19. Liu, J. et al. A predictive scoring system for the seroclearance of $\mathrm{HBsAg}$ in $\mathrm{HBeAg}$ - seronegative chronic hepatitis B patients with genotype B or C infection. J. Hepatol. 58, 853-860 (2013)

20. Seto, W. K. et al. A large case- control study on thepredictability of hepatitis B surface antigen levels three years before hepatitis B surface antigen seroclearance. Hepatology 56, 812-819 (2012)
21. Papatheodoridis, G. et al. Changes of HBsAg andinterferon- inducible protein 10 serum levels in naïve HBeAg- negative chronic hepatitis B patients under 4-year entecavir therapy. J. Hepatol. 60, 62-68 (2014)

22. Papatheodoridis, G. et al. Serum HBsAg kinetics and usefulness of interferon- inducible protein 10 serum in $\mathrm{HBeAg}$ - negative chronic hepatitis B patients treated with tenofovir disoproxil fumarate. J. Viral Hepat. 22, 1079-1087 (2015)

23. Buti, M. et al. Tenofovir alafenamide versus tenofovir disoproxil fumarate for the treatment of patients with $\mathrm{HBeAg}$ - negative chronic hepatitis B virus infection: a randomised, double- blind, phase 3, non- inferiority trial. Lancet. Gastroenterol. Hepatol. 1, 196-206 (2016)

24. Cheng-Yuan Peng. Early hepatitis B surface antigen decline predicts treatment response to entecavir in patients with chronic hepatitis B. Sci Rep. 2017 Feb 21;7:42879

25. Jeng WJ et al. Great and rapid HBsAg decline in patients with on-treatment hepatitis flare in early phase of potent antiviral therapy. J Viral Hepat. 2018 Apr;25(4):421-428

26. Maria G. Martinez. Biological basis for functional cure of chronic hepatitis B. J Viral Hepat. 2019 Jul;26(7):786-794

27. Chan $H L$, Thompson A, Martinot-Peignoux M, Piratvisuth $T$, Cornberg $M$, Brunetto MR, et al. Hepatitis B surface antigen quantification: Why and how to use it in 2011 - A core group report. J Hepatol 2011;55:1121-31. doi: 10.1016/j. jhep.2011.06.006.

28. Chan HL, Wong VW, Chim AM, Chan HY, Wong GL, Sung JJ. Serum $\mathrm{HBsAg}$ quantification to predict response to peginterferon therapy of e antigen positive chronic hepatitis B. Aliment Pharmacol Ther 2010;32:1323-31. doi: 10.1111/j.1365-2036.201 $0.04474 . x$

29. Zhang $X Q$, Zhang $H Y$, You JP, Mao Q. Efficacy of pegylated interferon $\mathrm{a} 2 \mathrm{a}$ in patients without HBeAg loss after the withdrawal of long-term lamivudine therapy. Virol J 2013;10:21. doi: 10.1186/1743-422X-10-21

30. Marcellin P, Bonino F, Yurdaydin C, Hadziyannis S, Moucari R, Kapprell HP, et al. Hepatitis B surface antigen levels: Association with 5-year response to peginterferon alfa-2a in hepatitis B e-antigen-negative patients. Hepatol Int 2013;7:88-97. doi: 10.1007/s12072-012-9343-x

31. Gish RG, Lau DT, Schmid P, Perrillo R. A pilot study of extended duration peginterferon alfa-2a for patients with hepatitis Be antigen-negative chronic hepatitis B. Am J Gastroenterol 2007;102:2718-23. doi: 10.1111/j.1572-0241.2007.01449.x

32. Okanoue T, Shima T, Hasebe C, Karino Y, Imazeki F, Kumada $T$, et al. Long-term follow up of peginterferon-a-2a treatment of hepatitis $\mathrm{B}$ e-antigen ( $\mathrm{HBeAg}$ ) positive and $\mathrm{HBeAg}$ negative chronic hepatitis B patients in phase II and III studies. Hepatol Res 2016;46:992-1001. doi: 10.1111/hepr.12638.।

33. Ma H, Yang RF, Wei L. Quantitative serum HBsAg and HBeAg are strong predictors of sustained $\mathrm{HBeAg}$ seroconversion to pegylated interferon alfa-2b in HBeAg-positive patients. J Gastroenterol Hepatol 2010;25:1498-506. doi: 10.1111/j.1440-174 6.2010.06282.x.

34. Brunetto MR. A new role for an old marker, HBsAg. J Hepatol 2010;52:475-7. doi: 10.1016/j.jhep.2009.12.020.

35. Jaroszewicz J, Calle Serrano B, Wursthorn K, Deterding K, Schlue J, Raupach R, et al. Hepatitis B surface antigen (HBsAg levels in the natural history of hepatitis $B$ virus (HBV)-infection: A European perspective. J Hepatol 2010;52:514-22. doi: 10.1016/j.jhep.2010.01.014.

36. Brunetto MR, Oliveri F, Colombatto P, Moriconi F, Ciccorossi $P$, Coco B, et al. Hepatitis B surface antigen serum levels help to distinguish active from inactive hepatitis $B$ virus genotype $D$ 
carriers. Gastroenterology 2010;139:483-90. doi: 10.1053/j. gastro.2010.04.052.

37. Moucari R, Mackiewicz V, Lada O, Ripault MP, Castelnau C, Martinot-Peignoux M, et al. Early serum HBsAg drop: A strong predictor of sustained virological response to pegylated interferon alfa-2a in HBeAg-negative patients. Hepatology 2009;49:1151-7. doi: 10.1002/hep.22744.

38. Brunetto MR, Moriconi F, Bonino F, Lau GK, Farci P, Yurdaydin $C$, et al. Hepatitis B virus surface antigen levels: A guide to sus- tained response to peginterferon alfa-2a in $\mathrm{HBeAg}$-negative chronic hepatitis B. Hepatology 2009;49:1141-50. doi: 10.1002/ hep. 22760

39. Li MH, Xie Y, Lu Y, Qiu GH, Liu F, Li XH, et al. High rates of HBsAg loss and seroconversion result from prolonged course of pegasys treatment (in Chinese). Chin J Hepatol 2011;19:182-5. doi:10.3760/cma.j.issn.1007-3418.2011.03.008. 